\title{
PENGARUH KEDISIPLINAN SISWA DAN MOTIVASI BELAJAR TERHADAP HASIL BELAJAR SELAMA PEMBELAJARAN JARAK JAUH JURUSAN TATA BOGA SMK ICB CINTA WISATA
}

\author{
Esra Megawati ${ }^{1}$ Sumeidi Kadarisman ${ }^{2}$ \\ ${ }^{1}$ Universitas Sangga Buana Ypkp \\ ${ }^{1}$ korespondensi : esramegawatiusbypkp@gmail.com
}

\begin{abstract}
Each school needs great HR, with the goal that the objectives of the school can be accomplished. Notwithstanding, to make this, it is important to focus on their privileges and commitments as understudies. The foundation of the planning of this postulation is the absence of understudy discipline and inspiration to learn. The purpose of this study is to find out and analyze student discipline, learning motivation and learning outcomes during distance learning in the culinary department of SMK ICB CINTA WISATA. This research method uses a descriptive verification method with a quantitative approach. The population of this study were students of SMK ICB CINTA WISATA majoring in culinary arts representing class X and XI. The example taken was 56 understudies and the examining procedure utilized the relative inspecting strategy. The information investigation strategy utilized different direct relapse examination, $F$ test and $T$ test. The aftereffects of the concentrate at the same time showed that there was a positive impact of understudy discipline and learning inspiration on learning results during distance learning. Partially, student discipline has no significant effect on learning outcomes. Meanwhile, learning motivation has a significant effect on learning outcomes during distance learning.
\end{abstract}

Keywords: Student Discipline, Learning Motivation, Learning Outcomes

\begin{abstract}
ABSTRAK
Setiap sekolah membutuhkan SDM yang besar, dengan tujuan agar tujuan sekolah dapat tercapai. Namun, untuk mewujudkannya, penting untuk fokus pada hak istimewa dan komitmen mereka sebagai siswa. Landasan perencanaan postulat ini adalah tidak adanya disiplin siswa dan inspirasi untuk belajar. Tujuan dari penelitian ini yaitu untuk mengetahui dan menganalisa tentang kedisiplinan siswa, motivasi belajar serta hasil belajar selama pembelajaran jarak jauh jurusan tata boga SMK ICB CINTA WISATA. Metode penelitian ini menggunakan metode penelitian deskriptif verifikatif dengan pendekatan kuantitatif. Populasi dari penelitian ini adalah siswa siswi SMK ICB CINTA WISATA jurusan tata boga yang mewakili kelas X dan XI. Contoh yang diambil adalah 56 siswa dan prosedur pemeriksaan menggunakan strategi pemeriksaan relatif. Strategi investigasi informasi menggunakan pemeriksaan kekambuhan langsung yang berbeda, uji $\mathrm{F}$ dan uji $\mathrm{T}$. Efek samping konsentrat sekaligus menunjukkan adanya pengaruh positif disiplin siswa dan inspirasi belajar terhadap hasil belajar selama pembelajaran jarak jauh. Secara parsial kedisiplinan siswa tidak berpengaruh signifikan terhadap hasil belajar. Sedangkan motivasi belajar sangat berpengaruh secara signifikan terhadap hasil belajar selama pembelajaran jarak jauh.
\end{abstract}

Kata Kunci: Kedisiplinan Siswa, Motivasi Belajar, Hasil Belajar

\section{PENDAHULUAN}

Pengajaran sebagai salah satu cara untuk membangun aset dalam suatu negara, dipercaya melalui sekolah para siswa dapat mengawal isu-isu kehidupan dan isu-isu di arena publik dengan mengambil bagian di arena publik dan memiliki pilihan untuk bersaing di era globalisasi.
Pada masa pandemi covid 19 seperti saat ini, dimana semua bidang mengalami perubahan termasuk dunia Pendidikan. Pendidikan merupakan salah satu modal pembangunan, karena tujuannya adalah untuk menciptakan sumber daya manusia (SDM) yang berkualitas. Untuk menciptakan hasil belajar selama pembelajaran jarak jauh bagi setiap siswa yang 
memiliki latar belakang individu yang berbeda-beda tentu tidak mudah, perlu adanya beberapa faktor pendorong berbagai cara,diantaranya mengkondisikan kedisplinan siswa yang baik dan kondusif serta memberikan motivasi pada setiap siswa.

Disiplin siswa mempengaruhi hasil belajar siswa karena, dalam hal siswa memiliki mentalitas terkendali yang berkembang di dalam siswa, sistem pembelajaran akan metodis dan lancar sehingga hasil yang didapat akan meningkat. Selain disiplin, inspirasi siswa juga dapat mempengaruhi hasil belajar. Inspirasi belajar sangat penting mengingat inspirasi dapat memberikan penghiburan bagi siswa, terutama di masa pandemi seperti ini. Jika tidak ada inspirasi, maka akan melemahkan semangat belajar sehingga mahasiswa yang belajar tanpa inspirasi tidak akan berhasil secara ideal.

Hasil belajar bukan hanya di ukur dari absensi siswa, melainkan dapat dilihat dari sikap siswa dalam menyelesaikan tugas untuk mencapai hasil belajar yang efektif.

Hasil wawancara yang dilakukan penulis terhadap masalah yang ada di sekolah SMK ICB CINTA WISATA, penulis melihat bahwa kedisplinan siswa dan motivasi belajar masih kurang. Banyak di antara siswa yang masih belum memperhatikan ketepatan waktu, sehingga sering adanya keterlambatan dalam mengakses link pembelajaran dan keterlambatan pengumpulan tugas yang telah diberikan. Dilihat dari aspek kedisplinan masih terdapat siswa kurang kedisplinan dalam menaati peraturan sekolah. Khususnya ada beberapa anak yang presentasi kehadirannya kurang, tidak mengerjakan tugas dan tidak mengikuti pembelajaran. Terkadang guru sudah merasa cukup dalam menjelaskan tugas kepada siswanya, namun hal tersebut ternyata belum di rasakan oleh siswa sehingga hasilnyapun tidak sesuai harapan. Motivasi belajar dapat dibilang rendah karena guru merasa kurangnya pengawasan yang dilakukan kepada siswanya, dengan adanya hal tersebut membuat siswa menjadi menyepelekan perihal pengerjaan tugas dan hasil belajar selama pembelanjaran jarak jauh belum maksimal karena masih ada beberapa siswa yang kurang aktif dalam diskusi, mengerjakan tugas, dan kehadiran.

\section{TINJAUAN PUSTAKA}

\section{Kedisiplinan Siswa}

Kedisiplinan sangat penting dan dibutuhkan oleh setiap siswa dengan menjadi prasyarat bagi pembentukan sikap, perilaku, dan tata kehidupan yang akan mengantarkan seorang siswa sukses dalam beajar dan bekerja kelak. Kedisiplinan siswa merupakan faktor yang berasal dari dalam diri siswa yang dapat mempengaruhi pencapaian hasil belajar siswa di sekolah [1]. Sikap seseorang dalam berperilaku yang terbentuk melalui serangkaian proses dan memiliki ketaatan terhadap norma atau peraturan sekolah yang akan mempengaruhi pencapaian hasil belajar siswa.

\section{Motivasi Belajar}

Motivasi merupakan pendorong seseorang untuk melakukan suatu kegiatan yang menentukan arah perbuatan,yakni ke arah 
tujuan yang hendak dicapai dimana dengan motivasi dapat memberikan arah dan kegiatan yang harus dikerjakan untuk mencapai tujuan. Motivasi belajar adalah keseluruhan daya penggerak dalam diri siswa yang menimbulkan kegiatan belajar, yang menjamin kelangsungan dari kegiatan belajar dan memberikan arah pada kegiatan belajar, sehingga tujuan yang dikehendaki oleh subjek belajar dapat tercapai. Motivasi belajar memiliki dimensi sebagai berikut:

1. Dimensi intrinsik yang terdiri dari adanya hasrat dan keinginan berhasil, adanya dorongan dan kebutuhan dalam belajar, serta adanya harapan dan cita-cita masa depan.

2. Dimensi ekstrinsik yang terdiri dari adanya penghargaan dalam belajar, adanya kegiatan yang menarik dalam belajar dan adanya lingkungan belajar yang kondusif [2].

\section{Hasil Belajar}

Hasil belajar pada dasarnya adalah hasil akhir yang diharapkan dapat dicapai setelah seseorang belajar. Hasil belajar di peroleh dari pembelajaran offline dan online sehingga mempengaruhi kedisiplinan siswa dan motivasi belajar. Hasil belajar merupakan ukuran kuantitatif yang mewakili kemampuan yang dimiliki siswa [3]. Terdapat faktor yang mempengaruhi hasil belajar diantaranya faktor internal dan faktor eksternal. Dengan adanya pandemi saat ini dunia pendidikan menggunakan pembelajaran jarak jauh (daring) yang menfaatkan teknologi. Pembelajaran daring adalah cara baru dalam pembelajaran dengan memanfaatkan perangkat elektronik berupa gawai atau leptop khususnya pada akses internet dalam penyampaiannya dalam pembelajaran, sehingga pembelajaran daring sepenuhnya bergantung kepada akses jaringan internet [4].

\section{Paradigma Penelitian}

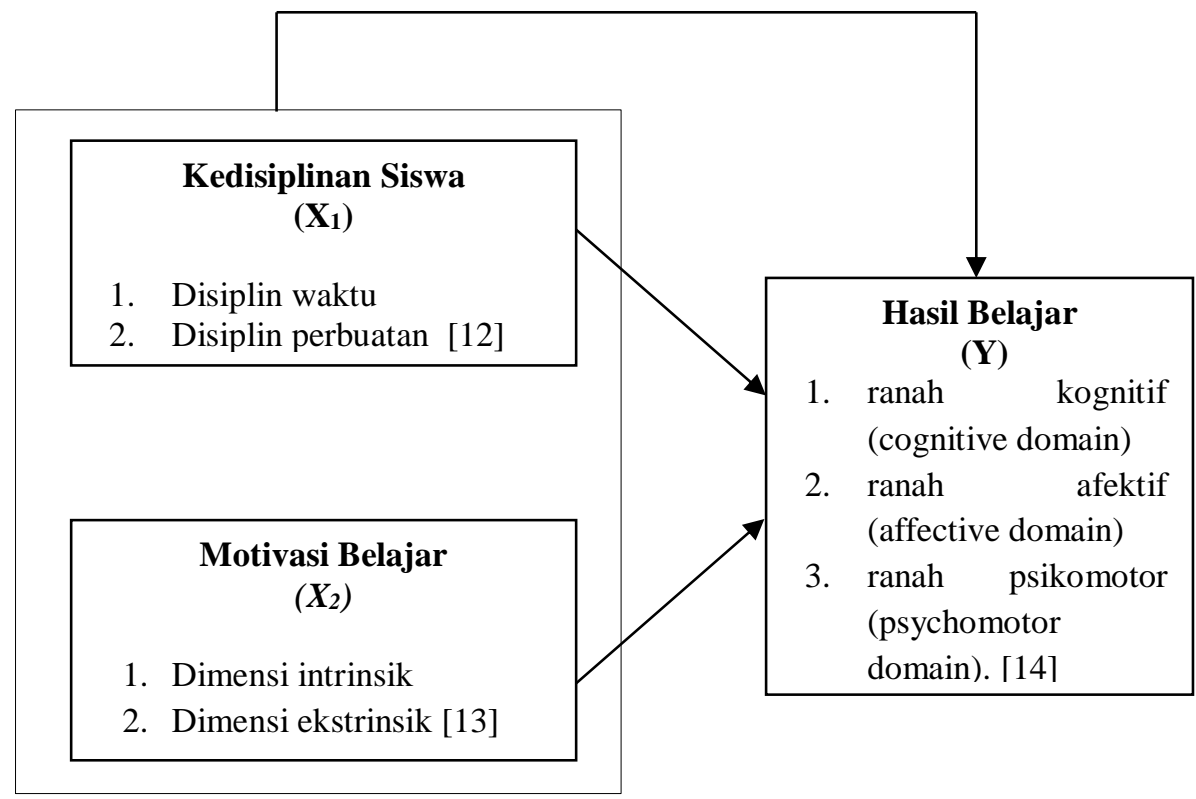

Gambar 1 : Paradigma Penelitian 
Pengaruh kedisiplinan siswa terhadap hasil belajar

Disiplin berkaitan dengan sistem pembelajaran, memiliki hubungan yang terkendali antara pendidik dan siswa dan iklim sebagai metode komunikasi, misalnya peraturan sekolah, tujuan pembelajaran, dan peningkatan siswa dalam pembelajaran melalui arahan guru.

Kesadaran diri merupakan salah satu faktor dimana seseorang memahami dan mengerti bahwa kedisplinan siswa penting bagi kebaikan dan keberhasilan dirinya. Ketika seseorang atau siswa menyadari bahwa kedisplinan penting maka siswa akan selalu senantiasa berdisiplin yang nantinya hasil belajar siswa di rumah atau di sekolah menjadi lebih baik.

Hal ini juga didukung dengan penelitian yang dilakukan oleh Ginting, Afer Heski tentang pengaruh Disiplin belajar siswa terhadap prestasi belajar siswa pada mata pelajaran IPA hubungan terhadap hasil belajar, karena dalam motivasi belajar berpengaruh terhadap hasil belajar jika siswa memiliki motivasi belajar yang tinggi maka akan mendapatkan hasil belajar yang baik, Lagi pula, siswa yang tidak memiliki inspirasi untuk belajar tidak akan bersemangat dan tidak bertanggung jawab atas tugas yang diberikan [5]. Hal ini dikarenakan pada siswa tidak ada kenyamanan untuk menyelesaikan latihanlatihan pembelajaran.pelajaran IPA Kelas IV SD Negeri 101836 Kuala T.A 2018/2019.
Pengaruh Motivasi Belajar Terhadap Hasil Belajar

Motivasi yang ada dalam diri siswa ditunjukkan dengan adanya minat dan perhatian siswa terhadap pelajaran, semangat siswa yang tinggi untuk melakukan tugas belajarnya, tanggung jawab siswa dalam mengerjakan tugas belajarnya, reaksi yang ditunjukkan siswa terhadap stimulus yang diberikan guru, serta memiliki rasa senang dan puas dalam mengerjakan tugas yang diberikan oleh guru [6] .

Penelitian di atas juga diperkuat oleh penelitian yang dilakukan oleh Intan Indah Wulansari yang menunjukkan bahwa motivasi belajar mempunyai pengaruh yang positif dan signifikan terhadap hasil belajar, dimana hasil belajar yang tinggi dapat dibentuk oleh adanya motivasi belajar yang meningkat [7]. Maka motivasi belajar memiliki pengaruh terhadap hasil belajar karena motivasi belajar yang baik akan berujung pada pencapaian hasil belajar yang optimal yang akan membuat siswa menjadi bersemangat belajar.

\section{Pengaruh Kedisiplinan siswa dan Motivasi} belajar terhadap Hasil belajar

Kedisipinan sangat berkaitan erat dengan Motivasi belajar salah satu yang mempengaruhi perkembangan disiplin adalah pemahaman tentang diri dan Motivasi belajar. Motivasi sangatlah penting bagi siswa, karena akan mendorong siswa untuk memperoleh hasil belajar yang lebih baik, sehingga siswa akan terus giat dalam belajar. Kedisiplinan siswa dan Motivasi belajar 
merupakan unsur penting dalam upaya belajar. Kedisiplinan siswa yang baik dan Motivasi belajar yang baik serta dapat mempengaruhi hasil belajar yang tentu nantinya akan meningkatkan prestasi siswa.

Kedisiplinan siswa dan Motivasi belajar sangat berhubungan dengan Hasil belajar siswa. Kedisiplinan siswa dan Motivasi belajar merupakan satu hal yang penting berpengaruh terhadap Hasil belajar. Kedisiplinan sangat penting karena dengan kedisiplinan siswa dalam Motivasi belajar maka siswa teratur sehingga Hasil belajar mereka juga maksimal. Hal ini juga didukung dengan penelitian yang dilakukan oleh peneliti Gustina Fatma Pertiwi yang menunjukkan bahwa Kedisiplinan siswa dan Motivasi belajar yang ada dalam siswa merupakan faktor penting dalam mempengaruhi Hasil belajar [8].

Hal ini menunjukkan adanya tingkat keeratan hubungan antara Kedisiplinan siswa dan Motivaasi belajar terhadap Hasil belajar yang mempunyai pengaruh berkesinambungan.

Berdasarkan paradigma penelitian, maka hipotesis yang diajukan dalam penelitian ini adalah :

"Secara parsial maupun simultan, diduga Kedisiplinan siswa dan Motivasi belajar berpengaruh terhadap Hasil belajar Selama Pembelajaran Jarak Jauh Jurusan Tata Boga SMK ICB CINTA WISATA".

\section{METODE PENELITIAN}

Penelitian ini dilakukan di sekolah SMK ICB CINTA WISATA. Populasi pada penelitian ini adalah siswa-siswi yang mewakili kelas $\mathrm{X}$ dan XI Jurusan Tata Boga. Teknik pengambilan sampel menggunakan proportienet stratified random sample atau teknik pengambilan sampel proposional, dimana sampel yang didapat berjumlah 56 siswa. Untuk membantu peneliti mendapatkan jawaban dari responden, digunakan alat bantu kuesioner yang berisi pertanyaan tertutup dengan serangkaian alternatif pilihan jawaban yang terdapat didalam kuesioner. Alternatif jawaban yang terdapat dalam kuesioner merupakan pengembangan dari setiap item dalam variabel penelitian. Dalam penelitian ini indikator-indikator diukur dengan menggunakan skala likert. Peneliti melakukan pengujian uji validitas dan uji realibilitas.

Selanjutnya dari data yang valid masuk, dilakukan teknik analisis data. Analisis data dibagi menjadi analisis deskriptif dan analisis verifikatif [9]. Analisis deskriptif digunakan untuk memberikan gambaran responden sedangkan analisis verifikatif bertujuan untuk mengetahui hubungan antar kedua variabel [10]. Analisis regresi liner berganda dalam penelitian ini bertujuan untuk mengetahui besarnya pengaruh variabel independen (kedisiplinan siswa dan motivasi belajar) terhadap variabel dependen (hasil belajar) dengan menggunakan rumus :

$\mathrm{Y}=\alpha+\beta_{1} \mathrm{X}_{1}+\beta_{2} \mathrm{X}_{2}+\mathrm{e}$

Keterangan :

Y

: Variabel dependen, yaitu

Hasil belajar

$\mathrm{X}_{1}, \mathrm{X}_{2} \quad$ : Variabel independen $\left(\mathrm{X}_{1}\right.$

Kedisiplinan siswa, $\mathrm{X}_{2}$ Motivasi belajar) 

a
: Konstanta
$\beta_{1} \beta_{2}$
: Koefisien regresi

\section{HASIL DAN PEMBAHASAN}

\section{Gambaran Responden}

Hasil yang diperoleh dari responden, berdasarkan jenis kelamin, didominasi oleh siswa berjenis kelamin perempuan, yaitu sebanyak 32 siswa atau 55,4\% pada kelas X dan kelas XI. Sedangkan berdasarkan kelas X yaitu sebanyak 48,2\% siswa sedangkan kelas XI sebanyak $51,8 \%$ siswa.

\section{Uji Validitas}

Uji validitas di gunakan untuk mengukur valid atau tidaknya setiap item dalam suatu kuesioner dalam penelitian. Dinyatakan valid jika item koesioner memiliki nilai $r$ hitung $>r$ tabel. Dalam penelitian ini memiliki 22 item pernyataan, semua item pernyataan valid karena semua item pernyataan memiliki $r$ hitung > $\mathrm{r}$ tabel $(0,218)$.

\section{Uji Reliabilitas}

Uji reliabilitas digunakan untuk melihat stabilitas atau konsistensi hasil pengukuran. Dalam penelitian ini menunjukan semua item pernyataan adalah reliabel karena semua variabel memiliki nilai t hitung > Cronbach Alpha (0,60).

\section{Uji Normalitas}

Tabel 1 : Hasil Uji Normalitas

\begin{tabular}{|c|c|c|}
\hline \multicolumn{3}{|c|}{ One-Sample Kolmogorov-Smirnov Test } \\
\hline & & Unstandardized Residual \\
\hline \multicolumn{2}{|l|}{$\mathrm{N}$} & 56 \\
\hline \multirow[t]{2}{*}{ Normal Parameters ${ }^{a, b}$} & Mean & .0000000 \\
\hline & Std. Deviation & 3.41380960 \\
\hline \multirow[t]{3}{*}{ Most Extreme Differences } & Absolute & .075 \\
\hline & Positive & .048 \\
\hline & Negative & -.075 \\
\hline \multicolumn{2}{|l|}{ Test Statistic } & .075 \\
\hline \multicolumn{2}{|l|}{ Asymp. Sig. (2-tailed) } & $.200^{c, d}$ \\
\hline \multicolumn{3}{|l|}{ a. Test distribution is Normal. } \\
\hline \multicolumn{3}{|l|}{ b. Calculated from data. } \\
\hline \multicolumn{3}{|c|}{ c. Lilliefors Significance Correction. } \\
\hline
\end{tabular}

Pada gambar terlihat titik-titik mengikuti dan mendekati garis diagonalnya, maka dapat disimpulkan bahwa model regresi memenuhi asumsi normalitas. 
Uji Multikolineritas

Tabel 2 : Hasil Uji Multikolineritas

\begin{tabular}{|c|c|c|}
\hline Variabel & Tolerance & VIF \\
\hline Kedisiplinan Siswa & .155 & 6.450 \\
\hline Motivasi Belajar & .155 & 6.450 \\
\hline
\end{tabular}

Sumber :Hasil Pengolahan Data Menggunakan SPSS Versi 26

Tabel diatas menunjukan semua variabel memiliki nilai tolerance $>0,10$ dan nilai VIF bebas tidak memiliki masalah $<10$.

multikolineritas, karena semua variabel

\section{Uji Heterosketisitas}

Tabel 3 : Hasil Uji Heterosketisitas

\begin{tabular}{|c|c|c|c|}
\hline \multicolumn{4}{|c|}{ Coefficients $^{a}$} \\
\hline \multicolumn{2}{|c|}{ Model } & $\mathrm{T}$ & Sig. \\
\hline \multirow[t]{3}{*}{1} & (Constant) & 3,703 &, 001 \\
\hline & Kedisilinan Siswa &,- 665 & ,509 \\
\hline & Motivasi Belajar &, 190 &, 850 \\
\hline
\end{tabular}

a. Dependent Variable: RES2

Sumber :Hasil Pengolahan Data Menggunakan SPSS Versi 26

Tabel diatas menunjukan semua variabel semua variabel memiliki nilai signifikasi tidak terjadi gejala Heterosketisitas karena (Sig.) $>0,05$.

\section{Uji Autokolerasi}

Tabel 4 : Hasil Uji Autokolerasi

\begin{tabular}{|c|c|c|c|c|c|}
\hline \multicolumn{6}{|c|}{ Model Summary ${ }^{b}$} \\
\hline Model & $\mathrm{R}$ & R Square & $\begin{array}{l}\text { Adjusted R } \\
\text { Square }\end{array}$ & $\begin{array}{l}\text { Std. Error } \\
\text { of the } \\
\text { Estimate }\end{array}$ & $\begin{array}{l}\text { Durbin- } \\
\text { Watson }\end{array}$ \\
\hline 1 & $.754^{\mathrm{a}}$ & .569 & .553 & 3.47762 & 1.838 \\
\hline \multicolumn{6}{|c|}{ a. Predictors: (Constant), Motivasi Belajar, Kedisiplinan Siswa } \\
\hline \multicolumn{6}{|c|}{ b. Dependent Variable: Hasil Belajar } \\
\hline
\end{tabular}

Dari tabel diatas menunjukan tidak terjadi autokolerasi karena hasil nilai Durbin Watson sebersar 1.838 yang artinya penelitian ini berada di atas 1 dan dibawah 3 .

\section{Uji T}

Tabel 5 : Hasil Uji T

\begin{tabular}{|c|c|c|c|c|c|c|}
\hline \multicolumn{7}{|c|}{ Coefficients $^{\mathrm{a}}$} \\
\hline & & \multicolumn{2}{|c|}{$\begin{array}{l}\text { Unstandardized } \\
\text { Coefficients }\end{array}$} & \multirow{2}{*}{$\begin{array}{c}\begin{array}{c}\text { Standardized } \\
\text { Coefficients }\end{array} \\
\text { Beta } \\
\end{array}$} & \multirow[b]{2}{*}{$\mathbf{T}$} & \multirow[b]{2}{*}{ Sig. } \\
\hline \multicolumn{2}{|c|}{ Model } & $\mathbf{B}$ & Std. Error & & & \\
\hline \multirow[t]{3}{*}{1} & (Constant) & 12.508 & 1.944 & & 6.432 & .000 \\
\hline & Kedisiplinan Siswa & .385 & .286 & .308 & 1.347 & .184 \\
\hline & Motivasi Belajar & .535 & .266 & .461 & 2.014 & .049 \\
\hline
\end{tabular}

Sumber :Hasil Pengolahan Data Menggunakan SPSS Versi 26 
Dengan melihat angka signifikasi dengan ketentuan jika angka signifikasi dibawah 0,10 maka hipotesis di tolak didapatkan bahwa untuk variabel kedisiplinan siswa (X1) secara parsial kedisiplinan siswa tidak berpengaruh signifikan terhadap hasil belajar. Hal ini terlihat dari angka signifikansi adalah 0,184. Sedangkan untuk variabel motivasi belajar (X2) berpengaruh signifikan terhadap hasil belajar hal ini terlihat dari angka nilai signifikasi yang adalah 0,49.

\section{Uji F}

Tabel 6 : Hasil Uji F

\begin{tabular}{|c|c|c|c|c|c|c|}
\hline \multicolumn{7}{|c|}{ ANOVA $^{a}$} \\
\hline \multicolumn{2}{|c|}{ Model } & Sum of Squares & Df & Mean Square & $\mathbf{F}$ & Sig. \\
\hline \multirow[t]{3}{*}{1} & Regression & 847.007 & 2 & 423.503 & 35.018 & $.000^{\mathrm{b}}$ \\
\hline & Residual & 640.975 & 53 & 12.094 & & \\
\hline & Total & 1487.982 & 55 & & & \\
\hline \multicolumn{7}{|c|}{ a. Dependent Variable: Hasil Belajar } \\
\hline
\end{tabular}

Sumber :Hasil Pengolahan Data Menggunakan SPSS Versi 26

Pada tabel diatas menunjukan bahwa variabel bebas memiliki F-hitung (35.018) > F-tabel $(2,41)$ dan nilai signifikasi $(0,000)<$ nilai propabilitas $(0,10)$. Maka Ha diterima dan Ho ditolak sehingga dapat diartikan bahwa variabel kedisiplinan siswa (X1) dan motivasi belajar (X2) secara bersama-sama memiliki pengaruh signifikan terhadap variabel hasil belajar (Y).

\section{Uji Linier Berganda}

Tabel 7 : Hasil Uji Linier Berganda

\begin{tabular}{|c|c|c|c|c|c|c|}
\hline \multicolumn{7}{|c|}{ Coefficients $^{\mathrm{a}}$} \\
\hline \multirow{2}{*}{\multicolumn{2}{|c|}{ Model }} & \multicolumn{2}{|c|}{$\begin{array}{c}\text { Unstandardized } \\
\text { Coefficients }\end{array}$} & \multirow{3}{*}{$\begin{array}{c}\begin{array}{c}\text { Standardized } \\
\text { Coefficients }\end{array} \\
\text { Beta } \\
\end{array}$} & \multirow{3}{*}{$\begin{array}{c}\mathbf{T} \\
6.432 \\
\end{array}$} & \multirow{3}{*}{$\begin{array}{l}\text { Sig. } \\
.000\end{array}$} \\
\hline & & B & Std. Error & & & \\
\hline \multirow[t]{3}{*}{1} & (Constant) & 12.508 & 1.944 & & & \\
\hline & Kedisiplinan Siswa & .385 & .286 & .308 & 1.347 & .184 \\
\hline & Motivasi Belajar & .535 & .266 & .461 & 2.014 & .049 \\
\hline
\end{tabular}

a. Dependent Variable: Hasil Belajar

$$
\text { Sumber :Hasil Pengolahan Data Menggunakan SPSS Versi } 26
$$

Dari tabel diatas tampak bahwa semua variabel independen maka semakin besar koefisien variabel independen adalah positif pula nilai variabel dependen. yang menunjukan makakin besar nilai 


\section{Uji Koefisien Determinasi}

Tabel 8 : Hasil Uji Koefisien Determinasi

\begin{tabular}{|l|c|r|r|r|}
\hline \multicolumn{5}{|c|}{ Model Summary } \\
\hline Model & $\mathrm{R}$ & R Square & $\begin{array}{c}\text { Adjusted R } \\
\text { Square }\end{array}$ & $\begin{array}{c}\text { Std. Error of the } \\
\text { Estimate }\end{array}$ \\
\hline 1 & $.754^{\mathrm{a}}$ & .569 & .553 & 3.47762 \\
\hline \multicolumn{5}{|c|}{ Sumber :Hasil Pengolahan Data Menggunakan SPSS Versi 26 }
\end{tabular}

Tabel diatas menunjukan Adjusted R Square sebesar 55,3\% hal ini berarti 55,3\% variabel hasil belajar dipengaruhi oleh kedisiplinan siswa dan motivasi belajar. Sedangkan sisanya sebesar $100 \%-55,3 \%=44,7 \%$ dipengaruhi oleh faktor lain yang tidak diteliti dalam penelitian ini.

\section{Pembahasan}

\section{Pengaruh Kedisiplinan siswa terhadap} Hasil belajar

Berdasarkan hasil pengujian yang dilakukan mengenai pengaruh dari kedisiplinan siswa terhadap hasil belajar berdasarkan hasil Parsial (Uji-t) diperoleh nilai signifikansi $0,184>0,10$ nilai $t_{\text {hitung }}<$ nilai $t_{\text {tabel }}(1.347$ $<$ 1.674) yang artinya Ho diterima dan $\mathrm{H}_{1}$ ditolak. Hal ini menunjukan bahwa tidak terdapat pengaruh dan tidak signifikan antara kedisiplinan siswa $\left(\mathrm{X}_{1}\right)$ terhadap hasil belajar (Y) selama pembelajaran jarak jauh jurusan tata boga SMK ICB CINTA WISATA. Hal ini didukung oleh penelitian Nastiti Amalda\&Lantip Diat Prasojo (2018) yang memperoleh hasil t-hitung $\leq \mathrm{t}$-tabel yang artinya bahwa kedisiplinan siswa tidak berpengaruh signifikan terhadap hasil belajar [11]. Dapat dilihat masih kurangnya kedisiplinan siswa dalam mengakses link pembelajaran dan mengerjakan tugas dengan tepat waktu.

\section{Pengaruh Motivasi Belajar terhadap Hasil Belajar}

Berdasarkan hasil penelitian yang dilakukan mengenai pengaruh dari motivasi belajar terhadap hasil belajar diperoleh hasil berdasarkan analisis regresi dinyatakan bahwa koefisien bernilai positif sebesar 0,535 . Hasil dari nilai tersebut memiliki arti bahwa motivasi belajar yang semakin baik dengan asumsi variabel lain konstan maka hasil belajar akan mengalami peningkatan sebesar 0,535.

Berdasarkan dari koefisien korelasi membuktikan bahwa terdapat keeratan hubungan yang kuat pengaruh antara variabel motivasi belajar terhadap hasil belajar yaitu 0,745 dengan nilai signifikansi $0,000<0,10$ yang artinya berkorelasi.

Sedangkan berdasarkan hasil pengujian secara parsial (Uji-t) variabel motivasi belajar (X2) berpengaruh positif dan signifikan terhadap hasil belajar (Y) artinya semakin tinggi motivasi belajar maka semakin tinggi pula hasil belajar. Hal ini dibuktikan dari nilai $t_{\text {hitung }}>$ nilai $t_{\text {tabel }}(2,014>1.674)$ maka Ho ditolak dan $\mathrm{H}_{1}$ diterima. Karena nilai 
signifikansi $0,049<0,10$ maka variabel kedisiplinan siswa berpengaruh positif dan signifikan terhadap hasil belajar selama pembelajaran jarak jauh jurusan tata boga SMK ICB CINTA WISATA.Karena motivasi belajar memiliki pengaruh yang positif dan signifikan terhadap hasil belajar maka SMK ICB CINTA WISATA harus mempertimbangkan motivasi belajar untuk meningkatkan hasil belajar.

Hasil ini menunjukkan bahwa semakin tinggi tingkat kemampuan siswa dalam melakukan kegiatan belajar yang efektif akan semakin meningkatkan hasil belajar siswa. Motivasi siswa termasuk dalam kategori tinggi atau baik nantinya akan dibuktikan dan ditunjukkan apabila siswa sudah mengikuti pembelajaran secara daring.

\section{Pengaruh Kedisiplinan Siswa dan} Motivasi Belajar terhadap Hasil Belajar

Berdasarkan hasil pengujian secara simultan (Uji F) kedisiplinan siswa (X1) dan motivasi belajar (X2) berpengaruh positif dan signifikan terhadap hasil belajar (Y). Hal ini dibuktikan dari nilai $\mathrm{F}_{\text {hitung }}>$ nilai $\mathrm{F}_{\text {tabel }}$ (35.018 > 2,41) maka Ho ditolak. Karena nilai signifikansi $0,000<0,10$ maka kedisiplinan siswa dan motivasi belajar berpengaruh positif dan signifikan terhadap hasil belajar selama pembelajaran jarak jauh jurusan tata boga SMK ICB CINTA WISATA.

Hasil pengujian determinasi pada penelitian ini didapatkan nilai koefisien determinasi (R Square) yaitu sebesar 0,569 atau sama dengan $56,9 \%$. Nilai tersebut menunjukan bahwa variabel kedisiplinan siswa $\left(\mathrm{X}_{1}\right)$ dan motivasi belajar $\left(\mathrm{X}_{2}\right)$ berkontribusi untuk mempengaruhi variabel hasil belajar (Y) sebesar 56,9\%, sedangkan sisanya $43,1 \%$ menunjukan bahwa masih ada faktor-faktor atau variabel-variabel lain yang tidak diteliti dalam penelitian ini. Hal ini disebabkan karena masih banyak faktor atau variabel lainnya yang juga dapat mempengaruhi hasil belajar.

\section{KESIMPULAN}

Berdasarkan hasil pembahasan sebelumnya dapat ditarik kesimpulan sebagai berikut :

Secara bersama-sama kedisiplinan siswa dan motivasi belajar berpengaruh terhadap hasil belajar hal ini ditunjukan dari hasil uji simultan dengan di peroleh dengan f-hitung sebesar 35.018 dengan probabilitas $0,000<$ 0,10 Hal ini ditujukan dari hasil parsial dengan memperoleh nilai t-hitung $1.347<\mathrm{t}$ tabel 1.674 sedangkan motivasi belajar berpengaruh positif terhadap hasil belajar. Hal ini ditunjukan dari hasil uji parsial memiliki niali t-hitung sebesar $2.014>1.674$. secara kontribusi secara bersama-sama kedisiplinan siswa dan motivasi belajar terhadap hasil belajar sebesar 55,3\% sedangkan sisanya $44,7 \%$ dipengaruhi oleh variabel lain yang tidak di teliti dari penelitian ini. Kedisiplinan siswa berpengaruh positif terhadap motivasi belajar.

\section{SARAN}

Berdasarkan kesimpulan di atas untuk mengantisipasi dan untuk tercapainya 
maksud dan tujuan peningkatan hasil belajar selama pembelajaran jarak jauh jurusan tata boga SMK ICB CINTA WISATA, maka dapat disarankan sebagai berikut :

1. Berdasarkan dari hasil distribusi jawaban responden pada variabel kedisiplinan siswa mendapatkan nilai rata-rata 2,82 berada dalam kategori cukup baik. Artinya kedisiplinan siswa harus meningkatkan ketepatan waktu dalam mengakses link pembelajaran dan ketepatan waktu dalam mengerjakan tugas serta bisa mengatur waktu belajar yang baik. Meningkatkan ketepatan waktu bisa dengan cara mengurangi waktu pelajaran selama pembelajaran jarak jauh berlangsung dan memberikan toleransi waktu untuk mengerjakan tugas diluar jam mata pelajaran agar kedisiplinan siswa berjalan dengan efektif.

2. Berdasarkan dari hasil distribusi jawaban responden pada variabel motivasi belajar mendapatkan nilai ratarata 3,05 berada dalam kategori cukup baik. Artinya motivasi belajar harus melakukan peningkatan dalam belajar yang kondusif agar siswa tidak jenuh pada saat pembelajaran berlangsung dan bisa menciptakan suasana belajar yang menyenangkan agar membuat siswa lebih bersemangat dalam belajar. Meningkatkan pembelajaran dengan kondusif, guru lebih bisa memahami siswa-siswinya dengan memberikan materi yang tidak terlalu rumit agar siswa-siswinya dapat memahami materi yang diberikan dan selalu memberikan contoh setiap penugasan agar siswasiswi bisa belajar dengan kondusif agar mudah mengerjakan setiap tugas yang diberikan.

3. Berdasarkan dari hasil distribusi jawaban responden pada variabel hasil belajar mendapatkan nilai rata-rata 3,07 berada dalam kategori cukup baik. Artinya hasil belajar diharapkan untuk lebih ditingkatkan dalam mengevaluasi pembelajaran dan memudahkan siswa dalam menerima materi sehingga tujuan pembelajaran tercapai secara maksimal. Meningkatkan evaluasi siswa bisa dilihat dari pengetahuan, keterampilan dan sikap serta bisa melihat keaktifan dalam diskusi dengan guru maupun perkelompok agar berani mengeluarkan pendapat masing-masing siswa, dalam menerima materi dengan mudah sebaiknya guru menggunakan teknologi yang bisa di akses oleh siswa seperti geoogle classroom,whatsaap,geoogle meet dan aplikasi edmodo tetapi alangkah baiknya sekolah memiliki aplikasi sendiri agar siswa tidak terlalu banyak mengakses aplikasi-aplikasi lainnya, maka dari itu siswa bisa menerima materi dengan mudah.

\section{DAFTAR PUSTAKA}

[1] A. Manazila, "Hubungan Motivasi Belajar dan Disiplin Siswa dengan Hasil Belajar PKn Kelas V," vol. 6, no. 1, pp. 61-70, 2017.

[2] M. Hakim and A. Mulyapradana, "Pengaruh Penggunaan Media Daring 
dan Motivasi Belajar Terhadap Kepuasan Mahasiswa Pada Saat Pandemi Covid-19," vol. 4, no. 2, pp. 154-160, 2020.

[3] S. Nurhalizah, "Pengaruh Motivasi Belajar dan Disiplin Belajar terhadap Prestasi Belajar Siswa pada Mata Pelajaran Akuntansi Keuangan Kelas XI Kompetensi Keahlian Akuntansi di SMK Negeri 1 Makassar," pp. 1-7.

[4] P. A, "Hasil Belajar 2018;84(5):48792,” pp. 13-34, 2018.

[5] A. . Ginting, "Pengaruh Disiplin Belajar Siswa Terhadap Prestasi Belajar Siswa pada Mata Pelajaran IPA Kelas IV SD Negeri 101836 Kuala T.A 2018/2019. 7-20," pp. 720, 2017.

[6] E. Novalinda, S. Kantun, and J. Widodo, "PELAJARAN AKUNTANSI SISWA KELAS $X$ JURUSAN AKUNTANSI SEMESTER GANJIL SMK PGRI 5 JEMBER TAHUN PELAJARAN 2016 / 2017," vol. 11, pp. 115-119, 2017, doi: 10.19184/jpe.v11i2.6456.

[7] I. I. Wulansari, "PENGARUH DISIPLIN BELAJAR DAN MOTIVASI BELAJAR TERHADAP PRESTASI BELAJAR SISWA SMP $\mathrm{N}$ 'X' SEMARANG,” vol. 011, pp. 1$5,2020$.

[8] G. F. Pratiwi, "Pengaruh Kedisiplinan Dan Motivasi Belajar Siswa Saat Pandemi Covid-19 Terhadap Hasil Belajar Ilmu Pengetahuan Alam Pada Siswa Kelas Viii Smp Negeri 2 Getasan Tahun Pelajaran 2019/2020.
Skripsi Program Studi Tadris Ilmu Pengetahuan Alam Fakultas Tarbiyah ,"2020.

[9] Sugiyono, No Title, Metode pen. Bandung: CV Alfabeta, 2018.

[10] Sugiyono, "Pengertian instrumen yang valid," Tinj. Keaktifan Belajar Siswa Pada Mata Pelajaran Ekon. Kelas XI Sma Pas. 7 Bandung, p. 121, 2017.

[11] L. D. P. Nastiti Amalda, "PENGARUH MOTIVASI KERJA GURU, DISIPLIN KERJA GURU, DAN KEDISIPLINAN SISWA TERHADAP PRESTASI BELAJAR SISWA," vol. 6, no. 1, pp. 11-21, 2018.

[12] N. F. Andhini, "Pengaruh Disiplin Belajar Siswa terhadap Hasil Belajar Siswa (Penelitian Kuantitatif Korelasi pada siswa kelas V Sekolah Dasar di Kecamatan Cibeunying Kaler Kota Bandung)," vol. 53, no. 9, pp. 16891699, 2017.

[13] M. I. R. Ratu Habibah Soleha, Indah Fitriyani and A. G. Adeline Roulia Rousere, "PENGGUNAAN MEDIA PEMBELAJARAN DI MASA SD DARUT TAUHID AR-RAFI TETAP MAKSIMAL," vol. 3, no. September 2021, pp. 454-467.

[14] N. Shova, "Pengaruh Kreativitas Guru IPS dan Lingkungan Sekolah Terhadap Hasil Belajar Siswa Kelas VIII MTS Negeri 7 Malang,” 2019. 